\title{
Synovial chondromatosis of the shoulder: imaging findings*
}

Osteocondromatose sinovial no ombro: achados por métodos de imagem

\section{Carlos Renato Ticianelli Terazaki ${ }^{1}$, Cesar Rodrigo Trippia ${ }^{2}$, Carlos Henrique Trippia ${ }^{3}$, Maria Fernanda Sales Ferreira Caboclo ${ }^{4}$, Carla Regina Miranda Medaglia ${ }^{1}$}

Terazaki CRT, Trippia CR, Trippia CH, Caboclo MFSF, Medaglia CRM. Synovial chondromatosis of the shoulder: imaging findings. Radiol Bras. 2014 Jan/ Fev;47(1):38-42.

Abstract Synovial chondromatosis is a benign condition characterized by synovial proliferation and metaplasia, with development of cartilaginous or osteocartilaginous nodules within a joint, bursa or tendon sheath. In the shoulder, synovial osteochondromatosis may occur within the glenohumeral joint and its recesses (including the tendon sheath of the biceps long head), and in the subacromial-deltoid bursa. Such condition can be identified either by radiography, ultrasonography or magnetic resonance imaging, showing typical features according to each method. Radiography commonly shows ring-shaped calcified cartilages and periarticular soft tissues swelling with erosion of joint margins. Ultrasonography demonstrates hypoechogenic cartilaginous nodules with progressive increase in echogenicity as they become calcified, with development of posterior acoustic shadow in case of ossification. Besides identifying cartilaginous nodules, magnetic resonance imaging can also demonstrate the degree of synovial proliferation. The present study is aimed at describing the imaging findings of this entity in the shoulder.

Keywords: Synovial chondromatosis; Image findings; Shoulder.

Resumo Osteocondromatose sinovial é uma afecção benigna caracterizada por proliferação e metaplasia sinovial, com formação de nódulos cartilaginosos ou osteocartilaginosos no interior de uma articulação, bursa ou bainha tendinosa. A osteocondromatose sinovial no ombro pode ocorrer no interior da articulação glenoumeral e seus recessos (incluindo a bainha do tendão da cabeça longa do bíceps) e na bursa subacrômio-deltoidiana. Esta doença pode ser identificada por radiografia, ultrassom ou ressonância magnética, apresentando aspectos característicos em cada um destes métodos. Na radiografia comumente encontramos calcificações anelares do tipo cartilaginoso e aumento de volume das partes moles periarticulares com erosões das margens articulares. No ultrassom os nódulos cartilaginosos apresentam-se hipoecogênicos, e quando calcificados aumentam progressivamente a sua ecogenicidade, até a formação de sombra acústica posterior quando ossificados. A ressonância magnética, além de identificar os nódulos cartilaginosos, também é capaz de mostrar o grau de proliferação sinovial. 0 objetivo deste trabalho é demonstrar os aspectos de imagem desta doença no ombro.

Unitermos: Osteocondromatose sinovial; Achados de imagem; Ombro.

\section{INTRODUCTION}

Synovial osteochondromatosis is a condition characterized by synovial membrane proliferation and metaplasia, with development of multiple cartilaginous or osteocartilaginous nodules within the joint, bursa or tendinous sheath ${ }^{(1)}$. It can be divided into primary and secondary forms ${ }^{(2)}$.

The primary form is uncommon, has unknown causes, and is generally monoarticular. It is between two to four times more frequent in men, occurring at any age group, most frequently between the $3 r d$ and 5 th decades of life ${ }^{(1-4)}$.

* Study developed at Hospital São Vicente - Funef, Curitiba, PR, Brazil.

1. MDs, Residents, Unit of Radiology and Imaging Diagnosis, Hospital São Vicente - Funef, Curitiba, PR, Brazil.

2. MD, Radiologist, Hospital São Vicente - Funef, Curitiba, PR, Brazil.

3. MD, Radiologist, Preceptor of Medical Residency, Unit of Radiology and Imaging Diagnosis, Hospital São Vicente - Funef, Curitiba, PR, Brazil.

4. MD, Radiologist, Head Preceptor of Medical Residency, Unit of Radiology and Imaging Diagnosis, Hospital São Vicente - Funef, Curitiba, PR, Brazil.

Mailing Address: Dr. Carlos Renato Ticianelli Terazaki. Rua Itajubá, 480, ap. 502, Portão. Curitiba, PR, Brazil, 81070-190. E-mail: reticianelli@hotmail.com.

Received December 19, 2012. Accepted after revision July 25, 2013.
Any joint may be affected, and the knee is the most frequent site (50-65\% of the cases), followed by elbow, hips and shoulder in decreasing order of frequency ${ }^{(2,5,6)}$.

The secondary form is a common condition caused by mechanical injury of the intraarticular hyaline cartilage triggered by joint anomalies such as osteoarthrosis, osteonecrosis, osteochondritis dissecans, neuropathic osteoarthropathy, trauma and rheumatoid arthritis ${ }^{(2,6)}$. It is found in elderly patients, generally involving multiple joints, and may be related to degenerative joint disease, more frequently in the knees, hips and shoulders ${ }^{(2)}$.

\section{FISIOPATHOLOGY}

The development of synovial osteochondromatosis in the shoulder joint is uncommon, and its secondary presentation is most frequently found. Cartilaginous or osteocartilaginous nodules may be found within the joint or its recesses (subscapularis, axillary and along the tendon sheath of the biceps long head), and in the subacromial-deltoid bursa. Patients with the primary presentation of the condition present with joint pain, swelling, and limitation of motion which 
progress slowly along many years ${ }^{(7,8)}$. In the secondary presentation, the symptoms are related to the basal joint disease and, in general, the condition is incidentally identified during investigation of degenerative joint disease, or in the course of investigations in patients with previously diagnosed joint disease who present with symptoms exacerbation. The physiopathology is the same for both presentations of the disease, and it may be divided into three phases. At the initial phase, synovial membrane proliferation and intrasynovial development of cartilaginous nodules (chondromas) occur. As the disease progresses, such cartilaginous nodules may calcify (osteochondromas), or even form mature ossified nodules with bone marrow ${ }^{(3)}$. At the late phase of the disease, active disease is no longer found in the synovia, and the nodules may detach towards the joint cavity forming loose bodies. In the primary form of the disease, the chondral nodules are usually numerous, with similar contours and morphology (ranging from a few millimeters up to some centimeters), which indicates that they originate simultaneously, sometimes coalescing and acquiring the appearance of a mass ${ }^{(2)}$. It is important to highlight, however, that in up to $30 \%$ of the patients no calcification is found ${ }^{(1)}$. In the secondary form of the disease, there is a lower number of synovial chondromas, with varied sizes and shapes, with a more irregular or ring-shaped calcification pattern, in concentric layers, besides the signs of degenerative joint disease.

The treatment for the primary presentation of the disease is the surgical removal of the intraarticular loose bodies and full synovectomy of the involved joint ${ }^{(6,9)}$. The recurrence rate ranges from $3 \%$ to $23 \%$, occurring within a period of up to five years, and the malignant transformation into chondrosarcoma is unusual (5\% of the cases). For the secondary presentation, the treatment is aimed at the symptoms of the osteodegenerative disease, and the possibility of arthroplasty is considered in cases of advanced disease.

\section{IMAGING FINDINGS}

The radiological findings depend on the presentation of the disease (either primary or secondary), on its stage and presence of calcification or ossification in the cartilaginous nodules ${ }^{(1,6)}$. In primary osteochondromatoses, conventional radiography can identify widened articular space and increase in volume of periarticular soft parts in association with erosion of joint margins, indicating the presence of disease of intraarticular origin ${ }^{(6)}$. Calcifications are usually numerous, sometimes countless, and similar in size and shape. Generally, calcifications are ring-shaped, of cartilaginous origin (Figure 1A) which gives them the typical radiographic aspect of such lesions ${ }^{(2,4,10,11)}$, sometimes presenting with a calcified central focus and ring-shaped peripheral calcification, or a target sign with a radiolucent center and calcified periphery. Periarticular osteoporosis is not commonly found.

In cases of secondary disease, the authors found signs of degenerative joint disease (intraarticular space narrowing, marginal osteophytes, sclerosis, and subchondral bone cysts) in association with a smaller number of calcifications with varied sizes, usually larger, calcifying in a more irregular form or in concentric layers (Figure 1B) $)^{(1,2)}$.

At ultrasonography, cartilaginous nodules are hypoechogenic (Figure 2), and as they calcify the echogenicity increases, sometimes determining posterior acoustic shadowing (Figure 3).

In the shoulder, ultrasonography is particularly sensitive to detect the disease affecting the tendon sheath of the biceps long head, demonstrating nodules attached to the

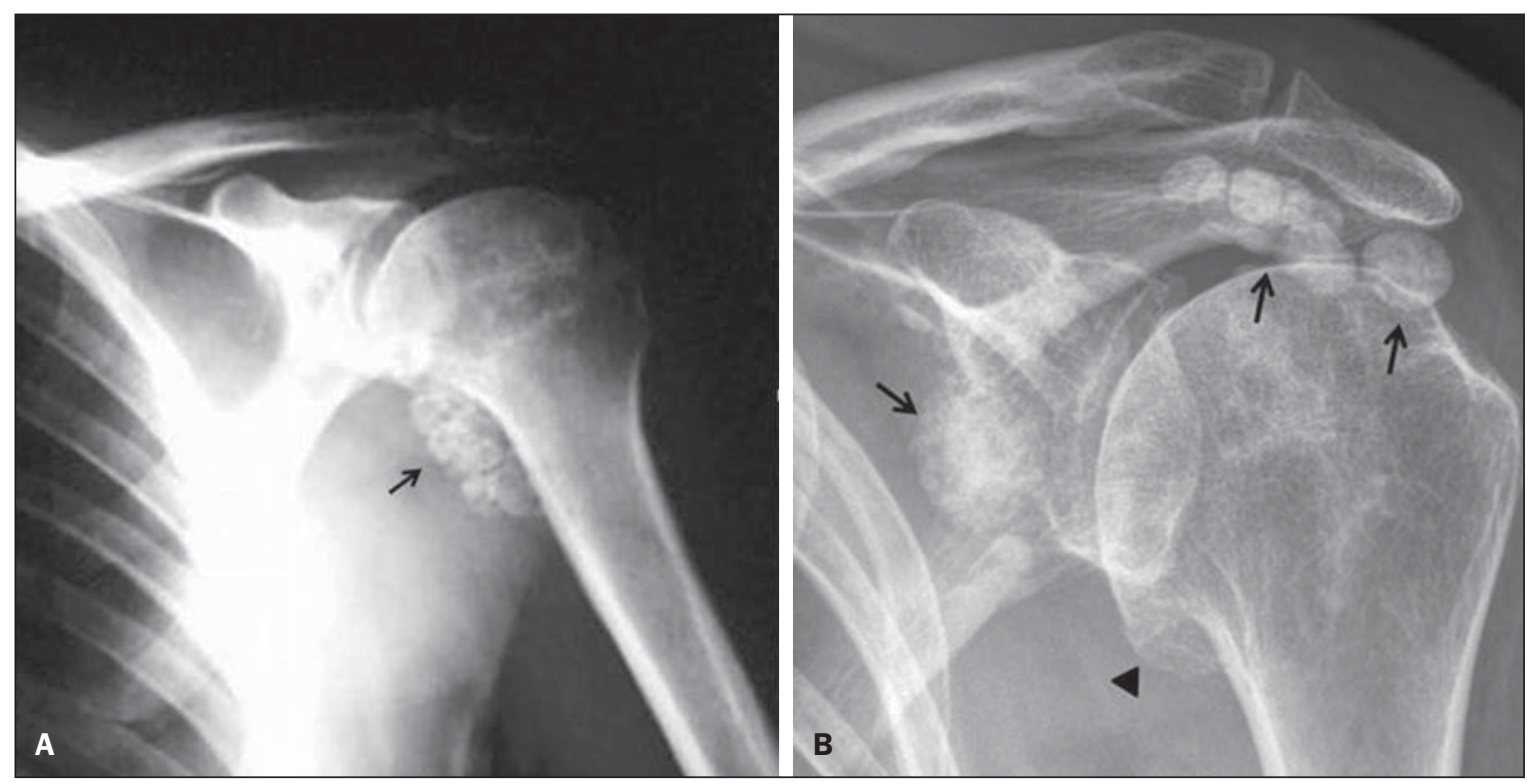

Figure 1. A: Primary synovial osteochondromatosis. Radiography, anteroposterior view of the shoulder demonstrating multiple, typical, ring-shaped calcifications similar in size and shape, located at the level of the axillary recess of the glenohumeral joint (arrow). B: Secondary synovial osteochondromatosis. Radiography, anteroposterior view of the shoulder demonstrating osteodegenerative changes characterized by the presence of osteophytes in the inferior articular margin of the humeral head (arrowhead) and presence of multiple juxtarticular rounded-shaped calcifications with varied sizes (arrows). 
synovial membrane surface, which is facilitated by the presence of fluid within the synovial sheath. Loose bodies are frequently found along the bicipital groove ${ }^{(9)}$. Such patients frequently have the secondary form of the disease associated with other alterations found upon examination of the shoulder, such as effusion in the joint and in the subacromial-deltoid bursa, tendinopathies and tendon tear (Figure 4).

Magnetic resonance imaging findings depend on the intensity of synovial proliferation, on the presence of cartilaginous nodules and calcifications ${ }^{(3)}$. Noncalcified lesions lead to synovial thickening (Figure 5) or to the development

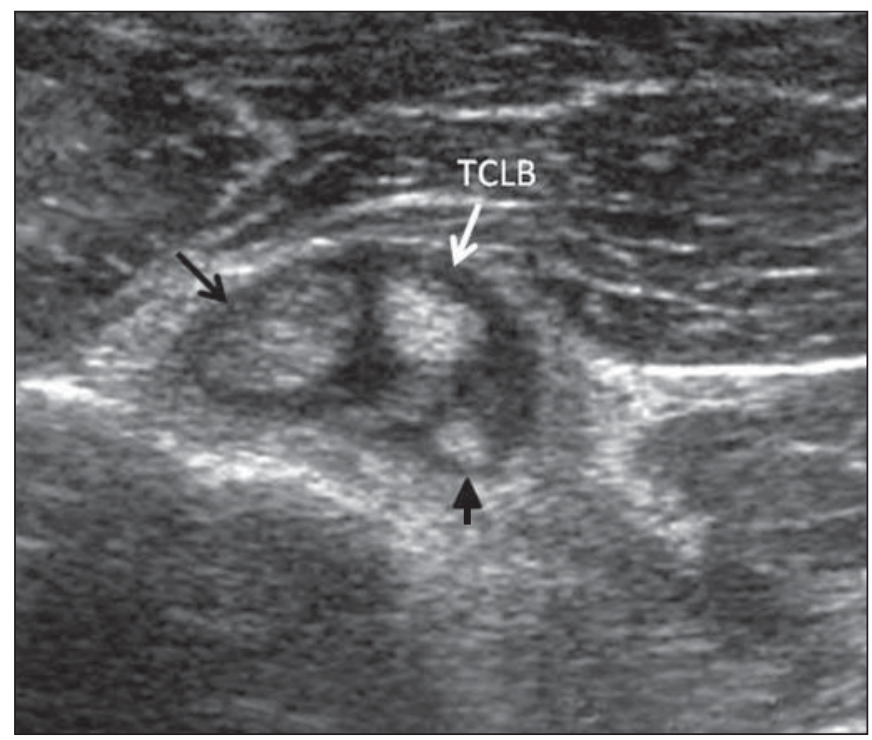

Figure 2. Secondary synovial osteochondromatosis. Sonographic study of the shoulder focusing the tendon of the biceps long head (TBLH) on the transverse plane. Presence of synovial nodules with different levels of echogenicity projecting toward the interior of the tendinous sheath, easily identifiable by the presence of synovial fluid. The echogenicity depends on the calcification degree, with hypoechoic nodules (black arrow) corresponding to noncalcified chondromas, while calcified nodules present increased echogenicity (arrowhead). of an isointense intraarticular mass isointense to the muscle on T1-weighted sequences, and hyperintense on T2-weighted sequences $^{(1-3,12)}$.

Such lesions may be differentiated from joint effusion or from other soft tissue tumors by the presence of the typical peripheral and septal contrast uptake of chondral lesions, after intravenous gadolinium injection ${ }^{(1,4)}$. The intravenous contrast is also useful in the detection of inflammatory activity of the disease by the presence of synovial uptake (Figure 6). Calcified nodules present low signal intensity on all utilized sequences (Figure 7$)^{(2,12)}$.

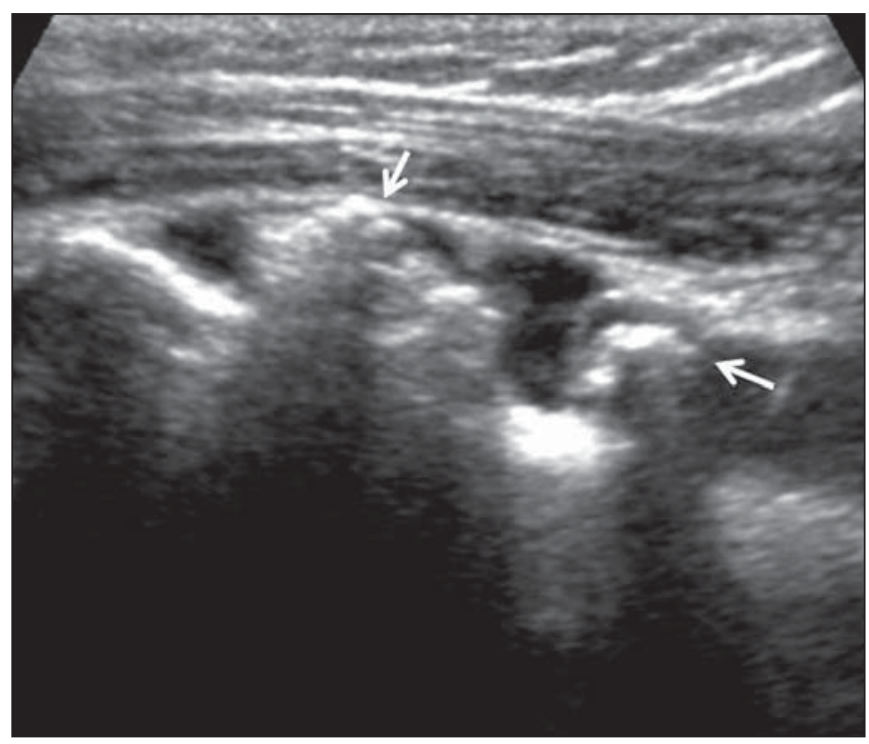

Figure 3. Secondary osteochondromatosis. Sonographic study of the shoulder, focusing the tendon sheath of the biceps long head on the longitudinal plane. The sheath is filled by fluid, and in its interior calcified nodules with posterior acoustic shadow are identified (arrows).
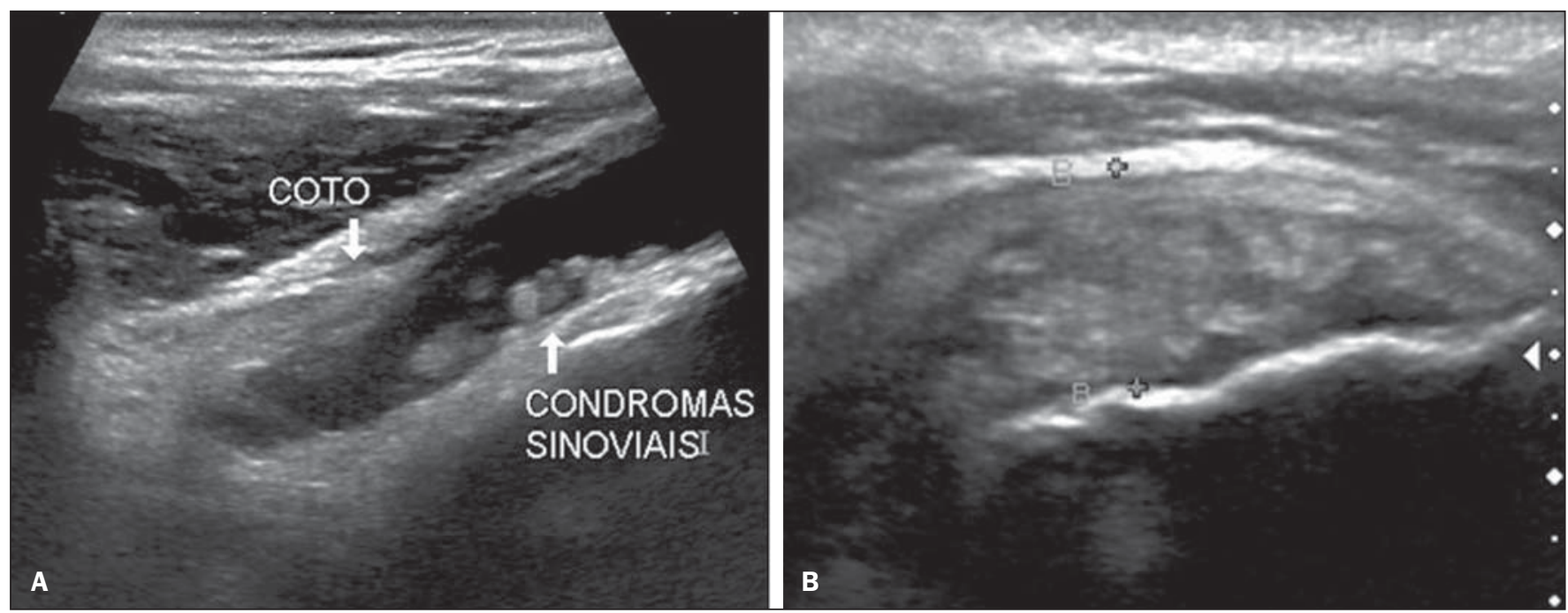

Figure 4. Secondary synovial osteochondromatosis associated with supraspinatus tendinopathy. A: Sonographic study of the shoulder focusing the tendon of the biceps long head on the longitudinal plane, which is ruptured, with only its proximal stump being identified. Multiple small synovial chondromas and effusion within the synovial sheath are observed. B: Longitudinal section of the supraspinatus tendon. Thickened, hypoechoic and heterogeneous tendon, with loss of fibrillar structure, characterizing tendinopathy process. 

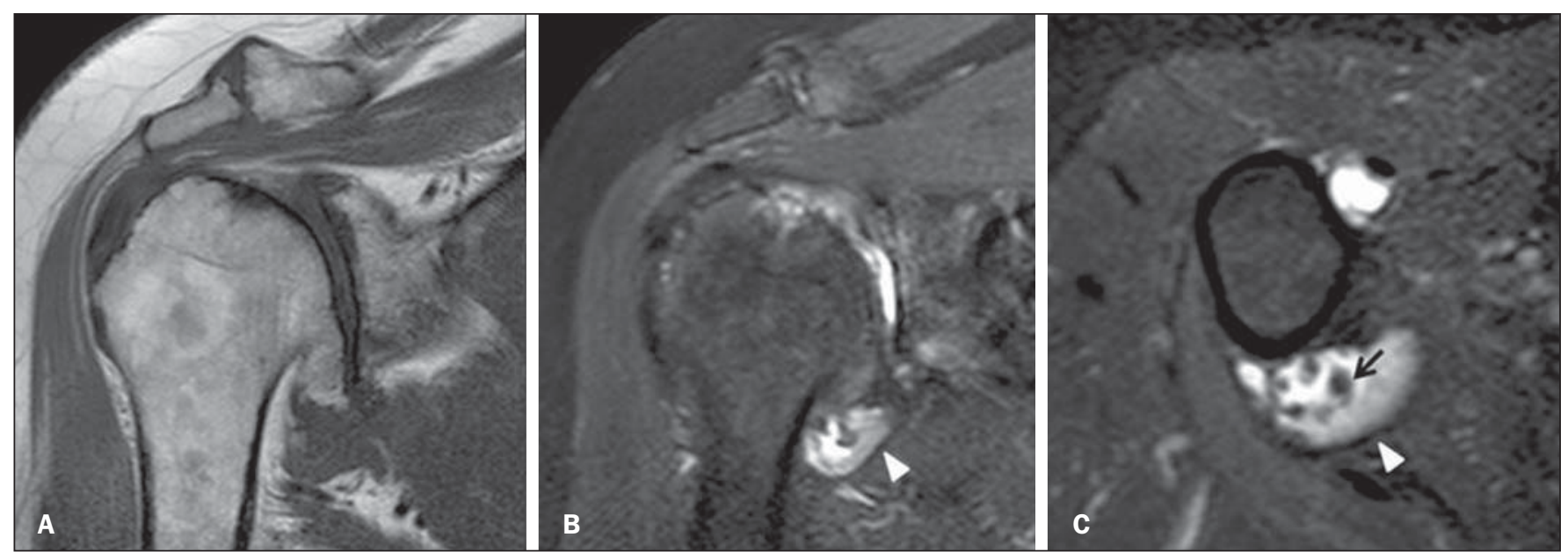

Figure 5. Secondary synovial osteochondromatosis. Magnetic resonance imaging, T1-weighted sequence of the shoulder in the coronal plane (A), coronal T2-weighted fat sat (B), and axial T2weighted fat sat (C) demonstrating marked osteodegenerative glenohumeral alteration characterized by irregularity of the joint surface and marginal osteophytes on the humeral head. Presence of synovial thickening in the axillary joint recess, with intermediate signal on T2-weighted sequence (arrowhead) and small synovial osteochondromas (arrow).

Figure 6. Primary synovial chondromatosis. Magnetic resonance imaging of the shoulder, coronal T2-weighted (A) and coronal T1-weighted fat sat sequence after intravenous gadolinium injection (B). Multiple, noncalcified synovial chondromas in the interior of the subacromial-deltoid bursa, hyperintense on T2-weighted sequence and isointense to the muscle on contrastenhanced T1-weighted sequence, symmetrical in size and shape. Presence of synovial membrane proliferation thickening of the bursa wall, with intermediate signal intensity on T2-weighted sequence with contrast uptake, indicating disease activity.

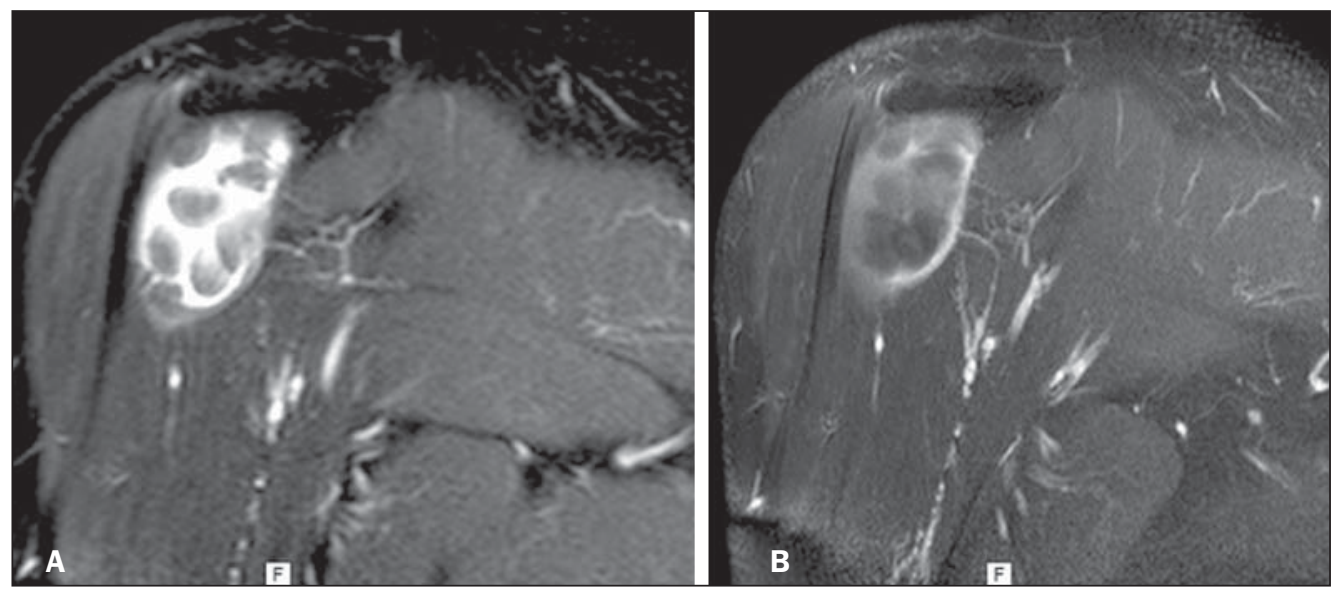

Figure 7. Secondary synovial osteochondromatosis. Magnetic resonance imaging of the shoulder, sagittal T1weighted (A) and sagittal T2-weighted fat sat (B) sequences. Presence of calcified nodules (synovial osteochondromas) in the subacromial-deltoid bursa (arrows) and in the subscapularis recess (arrowheads) with typical nodular features, with marked hyposignal on T1- and T2-weighted sequences.

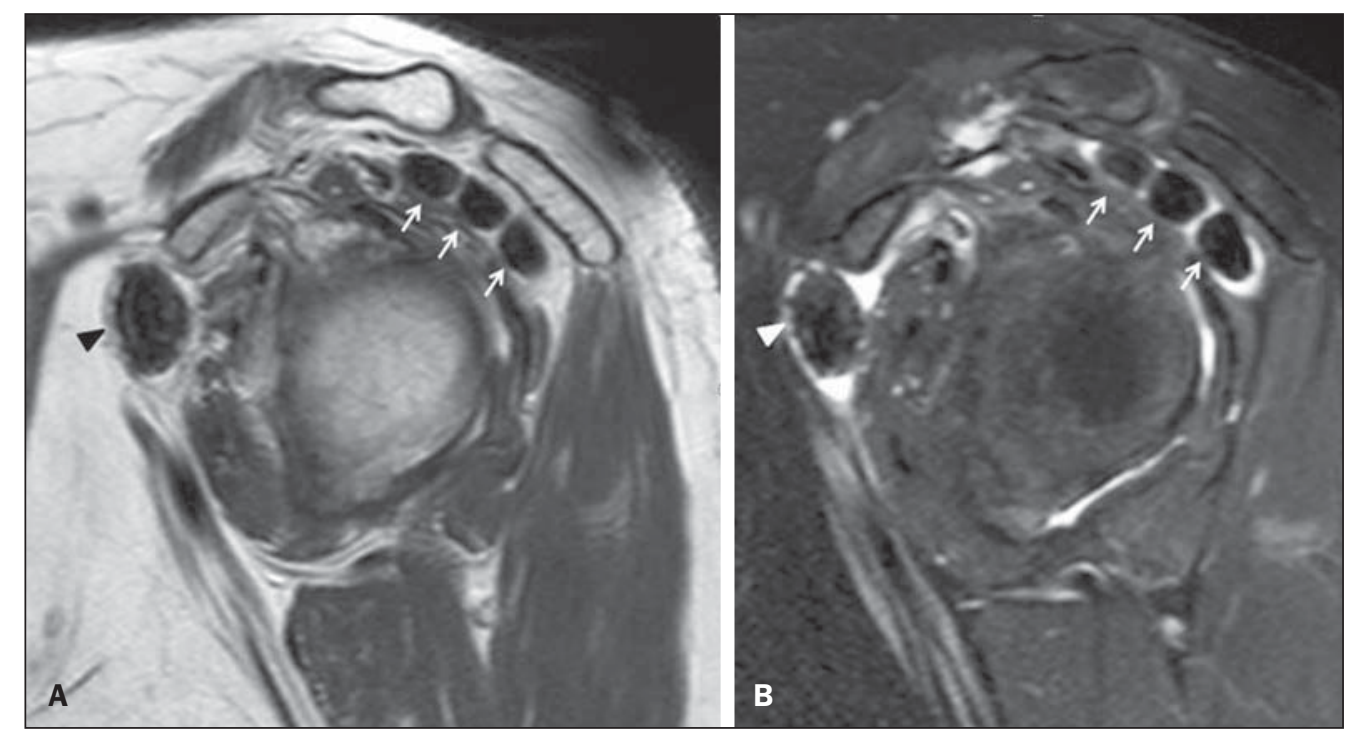

Intraarticular nodules that undergo endochondral ossification are formed by mature bone, present peripheral cortical bone with low signal intensity, and hyperintense yellow bone marrow within the bone on T1-weighted sequences ${ }^{(2,12)}$.

\section{CONCLUSION}

In spite of being less common than in other joints of the body, synovial osteochondromatosis may be found in the shoulder at the level of the joint recesses (including the ten- 
don sheath of the biceps long head) and in the subacromialdeltoid bursa. The primary and secondary presentations of the disease may be suggested by the number, shape and size of the chondral nodules, as well as by the absence or presence of pre-existing joint disease. The diagnosis may be achieved only on the basis of typical imaging findings which, depending on the stage of the disease, may correspond to synovial membrane proliferation, presence of cartilaginous nodules (chondromas) and calcified or ossified nodules (osteochondromas).

\section{REFERENCES}

1. Llauger J, Palmer J, Rosón N, et al. Nonseptic monoarthritis: imaging features with clinical and histopathologic correlation. Radiographics. 2000;20 Spec No:S263-78.

2. Murphey MD, Vidal JA, Fanburg-Smith JC, et al. Imaging of synovial chondromatosis with radiologic-pathologic correlation. Radiographics. 2007;27:1465-88.

3. Sheldon PJ, Forrester DM, Learch TJ. Imaging of intraarticular masses. Radiographics. 2005;25:105-19.

4. Walker EA, Murphey MD, Fetsch JF. Imaging characteristics of tenosynovial and bursal chondromatosis. Skeletal Radiol. 2011; 40:317-25.

5. Kransdorf MJ, Meis JM. Fom the archives of the AFIP. Extraskeletal osseous and cartilaginous tumors of the extremities. Radiographics. 1993;13:853-84

6. Mohana-Borges AV, Chung CB, Resnick D. Monoarticular arthritis. Radiol Clin North Am. 2004;42:135-49.

7. Milgram JW. Synovial osteochondromatosis: a histopatological study of thirty cases. J Bone Joint Surg Am. 1977;59:792-801.

8. Trajkovski T, Mayne IP, Deheshi BM, et al. Synovial chondromatosis of the shoulder: open synovectomy and insertion of osteoarticular allograft with internal fixation to repair intraoperative glenohumeral joint instability. Am J Orthop (Belle Mead NJ). 2011;40:E154-8.

9. Lunn JV, Castellanos-Rosas J, Walch G. Arthroscopic synovectomy, removal of loose bodies and selective biceps tenodesis for synovial chondromatosis of the shoulder. J Bone Joint Surg Br. 2007;89:1329-35.

10. Olsen KM, Chew FS. Tumoral calcinosis: pearls, polemics, and alternative possibilities. Radiographics. 2006;26:871-85.

11. Lasmar NP, Vieira RB, Rosa JO, et al. Condromatose sinovial. Rev Bras Ortop. 2010;45:490-2.

12. Domingues RC, Domingues RC, Brandão LA. Imagenologia do quadril. Radiol Bras. 2001;34:347-67. 